\title{
Cerebral salt wasting syndrome caused by severe traumatic brain injury: pediatric case report and review of the literature
}

\author{
Mohamed Aziz Daghmouri ${ }^{1}$, Maroua Oueslati ${ }^{1}$, Mohamed Amine Touati ${ }^{1}$, Olfa Faten ${ }^{1}$, \\ Sameh Zakhama ${ }^{1}$, and Lotfi Rebai ${ }^{2}$ \\ ${ }^{1}$ Centre de Traumatologie et des Grands Brules \\ ${ }^{2}$ University of Tunis El Manar Faculty of Medicine of Tunis
}

March 3, 2021

\begin{abstract}
Following acute traumatic brain injury, cerebral salt wasting (CSW) syndrome is considered as an important cause of hyponatremia apart from syndrome of inappropriate antidiuretic hormone. Differentiation between the two syndromes is crucial for the initiation of an adequate treatment. So we report a pediatric case.
\end{abstract}

\section{Title page}

Title: Cerebral salt wasting syndrome caused by severe traumatic brain injury: pediatric case report and review of the literature

Author:

- Mohamed Aziz Daghmouri (Department of Anesthesia, Trauma Center of Ben Arrous)

- Maroua Ouesleti (Department of Anesthesia, Trauma Center of Ben Arrous)

- Mohamed Amine Touati (Department of Anesthesia, Trauma Center of Ben Arrous)

- Olfa Faten (Department of Anesthesia, Trauma Center of Ben Arrous)

- Sameh Zakhama (Department of Anesthesia, Trauma Center of Ben Arrous)

- Lotfi Rebai (Department of Anesthesia, Trauma Center of Ben Arrous)

Corresponding author:

Mohamed Aziz Daghmouri

Mail:aziz.daghmouri@gmail.com

Phone : 0021629442474

Financial Disclosures:

None

Conflicts of interest:

None

Word count:

Abstract: 162

Entire body: 1841 
Author's contribution:

- Mohamed Aziz Daghmouri: This author helped in making the diagnostic, taking care of the patient and writing the first draft

- Maroua Ouesleti: This author helped in making the diagnostic and taking care of the patient

- Mohamed Amine Touati: This author helped in making the diagnostic and taking care of the patient

- Olfa Faten: This author helped in making the diagnostic and taking care of the patient

- Sameh Zakhama: This author helped in taking care of the patient

- Lotfi Rebai: This author helped in the revision of the manuscript

\section{Abstract:}

Background:

Following acute traumatic brain injury, cerebral salt wasting (CSW) syndrome is considered as an important cause of hyponatremia apart from syndrome of inappropriate antidiuretic hormone. Differentiation between the two syndromes is crucial for the initiation of an adequate treatment.

Case presentation:

We report a 15-year-old female adolescent, admitted to intensive care for acute severe traumatic brain injury. During his hospitalization, she developed a hyponatremia with an increase of urine output and hypovolemia. So, the most probable diagnosis was CSW. Initially she was treated by hypertonic saline and volume expansion. However, his sodium level continued to fall despite infusion of hypertonic saline. That is why fludrocortisone was introduced initially at $50 \mu \mathrm{g} /$ day then increased to $150 \mu \mathrm{g} /$ day. Fludrocortisone was continued for the next months. Serum sodium level was $138 \mathrm{mmol} / \mathrm{L}$ after one month of treatment.

\section{Conclusion:}

Hyponatremia may occur after severe traumatic brain injury that is why an adequate treatment initiated on time is necessary in order to reduce morbidity and mortality.

\section{Keywords:}

Cerebral Salt wasting, Hyponatremia, Syndrome of inappropriate antidiuretic hormone, Traumatic brain injury

\section{Introduction:}

Cerebral salt wasting (CSW) syndrome is an uncommon cause of hyponatremia in neurosurgical patients especially following traumatic brain injury. Distinguishing it from the more familiar syndrome of inappropriate antidiuretic hormone (SIADH) is crucial and it is vital to make rapidly the right diagnosis in order to start an appropriate treatment based on volume resuscitation and sodium restoration. Although CSW has rarely been studied in the traumatic brain injury population especially pediatric ones that is why we report a 15-year-old female child with acute brain injury complicated of CSW managed by saline hydration and fludrocortisone.

Written informed consent was obtained from the patient family for publication of this case report and accompanying images. This manuscript adheres to the SCARE guidelines.

\section{Case presentation:}

A 15-year-old female child was brought to the emergency department after a motor vehicle accident (pedestrian struck by motor vehicle). She had no significant past medical history and was not taking any regular medications. Initial physical examination revealed neurological distress with Glasgow come scale score of 4, decerebration and bilateral mydriasis. Pulse rate was $100 / \mathrm{min}$, blood pressure $120 / 65 \mathrm{mmHg}$, respiratory rate $30 / \mathrm{min}$ and oxygen saturation $95 \%$. Rapidly, she was intubated and received osmotherapy with hypertonic saline. 
Computed tomography revealed left fronto-temporal subdural hematoma $(6 \mathrm{~mm})$ with left temporal commitment and diffuse cerebral edema. Neurosurgical opinion was sought. Therefore, she was admitted to intensive care unit. Initial complete blood cell count and serum biochemistry were without abnormalities and serum sodium concentration was $140 \mathrm{mmol} / \mathrm{L}$.

On day 6 of admission, the patient presented a significant increase of urine output (more than $3 \mathrm{~mL} / \mathrm{kg} / \mathrm{h}$ ) with abnormalities in the transcranial doppler ultrasonography. It was due to a low sodium level $(124 \mathrm{mmol} / \mathrm{L})$. Possibility of cerebral salt wasting (CSW) and syndrome of inappropriate antidiuretic hormone (SIADH) was considered. Urine osmolality and urine sodium were $390 \mathrm{mosmol} / \mathrm{L}$ and $114 \mathrm{mmol} / \mathrm{L}$ respectively. She was also hypovolemic so referred to the endocrinologist and nephrologist opinion, CSW was the most suitable diagnostic.

Correction was started rapidly using hypertonic saline (2\% saline) and substantial volume replacement (equivalent of more than 3L/day of $2 \%$ saline) in order to restore serum sodium to low normal levels within $48 \mathrm{~h}$ (sodium $135 \mathrm{mmol} / \mathrm{L})$. Saline infusion (1.2\% saline) was given as maintenance fluid during his hospitalization. However, on day 12 of admission, his sodium level continued to fall despite infusion of hypertonic saline. That is why fludrocortisone was introduced initially at $50 \mu \mathrm{g} /$ day then increased to $150 \mu \mathrm{g} / \mathrm{day}$. Introduction of this molecule resulted in a fall in requirements for hypertonic saline. Although, starting from day 25 of admission, serum sodium levels remained stable around $135 \mathrm{mmol} / \mathrm{L}$ on fludrocortisone alone and she was discharged home 30 days post injury.

It worth noting that during his hospitalization, magnetic resonance imaging of the brain was done objectifying an encephalitis treated by antibiotics (Linezolid and Meropenem).

Fludrocortisone was continued for the next months. Serum sodium level was $138 \mathrm{mmol} / \mathrm{L}$ after one month of treatment. Since she was discharged, she has been followed by an endocrinologist.

\section{Discussion:}

Cerebral salt wasting is resulting in hyponatremia and poorly hypovolemia caused by renal loss of sodium following intracranial disorders (1) which was first described by Peters et al (2) in 1950. The mechanisms leading to CSW remain an area of debate and one of the hypothesis is that, after a brain injury, there is an increasing of levels natriuretic peptides hormones which inhibit sodium reabsorption and decrease release of renin (3).

It is important and complex to distinguish CSW from the syndrome of inappropriate secretion of antidiuretic of hormone (SIADH) as treatments are different. The combination of excess fluid and hyponatremia in SIADH is treated by water restriction whereas in CSW hypovolemia necessitates replacement of both water and sodium. It is crucial to treat hyponatremia correctly because it can worsen cerebral edema or result in seizure, however when it is sub-optimally treated, it would cause osmotic demyelination (4).

CSW is most commonly studies in patients with aneurysmal subarachnoid hemorrhage with high incidence of hyponatremia up to $57 \%$ according to sherlock et al (5). Although, traumatic brain injury (TBI) could be associated with hyponatremia, however literature studying CSW in TBI population is poor with little information available on physiopathology and outcomes. Furthermore, Leonard et al (6) found that incidence of CSW in TBI patients was from $0.8 \%$ to $34.6 \%$ and it was developed within days to two months postinjury. It occurs in patients of all ages but it has been suggested that CSW takes a different course in children compared to adults. Nine pediatric cases of CSW due to TBI were published in the literature as well as we know (Table 1). Three patients developed CSW two days post traumatic (7-9), two developed CSW after one week $(8,10)$ and four developed CSW between two weeks and two months post traumatic (11-14).

Concerning the management of CSW, it is based on the correction of intravascular volume depletion and hyponatremia. However, close monitoring of saline sodium level is crucial in order to prevent overly rapid correction of hyponatremia (15). Moreover, pharmacological intervention could be necessary in some cases especially Fludrocortisone which is recommended as a potential therapeutic option. Misra et al (16) proved 
that Fludrocortisone may result in earlier normalization of serum sodium in patients with cerebral salt wasting as a part of tuberculous meningitis.

\section{Conclusion:}

Hyponatremia could be present after traumatic brain injury. Every clinician should be aware of the importance of making the right diagnosis on time and distinguishing CSW from SIADH which they have opposite treatment. So, we reported this case in order to emphasize the role of initiating appropriate treatment rapidly in reducing morbidity and mortality of hyponatremia.

\section{References:}

1. Betjes MG, Koopmans RP. [Hyponatremia in acute intracranial disorders: cerebral salt wasting]. Ned Tijdschr Geneeskd. 2000 Mar 18;144(12):553-6.

2. Peters JP, Welt LG, Sims E a. H, Orloff J, Needham J. A salt-wasting syndrome associated with cerebral disease. Trans Assoc Am Physicians. 1950;63:57-64.

3. Yee AH, Burns JD, Wijdicks EFM. Cerebral salt wasting: pathophysiology, diagnosis, and treatment. Neurosurg Clin N Am. 2010 Apr;21(2):339-52.

4. Tam CW, Shum HP, Yan WW. Impact of Dysnatremia and Dyskalemia on Prognosis in Patients with Aneurysmal Subarachnoid Hemorrhage: A Retrospective Study. Indian J Crit Care Med. 2019 Dec;23(12):562-7.

5. Sherlock M, O'Sullivan E, Agha A, Behan LA, Owens D, Finucane F, et al. Incidence and pathophysiology of severe hyponatraemia in neurosurgical patients. Postgrad Med J. 2009 Apr;85(1002):171-5.

6. Leonard J, Garrett RE, Salottolo K, Slone DS, Mains CW, Carrick MM, et al. Cerebral salt wasting after traumatic brain injury: a review of the literature. Scand J Trauma Resusc Emerg Med [Internet]. 2015 Nov 11

7. Steelman R, Corbitt B, Pate MFD. Early onset of cerebral salt wasting in a patient with head and facial injuries. J Oral Maxillofac Surg. 2006 Apr;64(4):746-7.

8. Berkenbosch JW, Lentz CW, Jimenez DF, Tobias JD. Cerebral Salt Wasting Syndrome following Brain Injury in Three Pediatric Patients: Suggestions for Rapid Diagnosis and Therapy. PNE. 2002;36(2):75-9.

9. Ganong CA, Kappy MS. Cerebral salt wasting in children. The need for recognition and treatment. Am J Dis Child. 1993 Feb;147(2):167-9.

10. Donati-Genet PC, Dubuis JM, Girardin E, Rimensberger PC. Acute symptomatic hyponatremia and cerebral salt wasting after head injury: an important clinical entity. J Pediatr Surg. 2001 Jul;36(7):1094-7.

11. Chaudhary N, Pathak S, Gupta MM, Agrawal N. Cerebral Salt Wasting Syndrome following Head Injury in a Child Managed Successfully with Fludrocortisone. Case Reports in Pediatrics. 2016;2016:1-4.

12. Simsek E, Dilli D, Yasitli U, Ozlem N, Bostanci I, Dallar Y. Cerebral salt wasting in a child with cervicothoracic hematoma. J Pediatr Endocrinol Metab. 2008 Jul;21(7):695-700.

13. Askar A, Tarif N. Cerebral salt wasting in a patient with head trauma: management with saline hydration and fludrocortisone. Saudi J Kidney Dis Transpl. 2007 Mar;18(1):95-9.

14. Kappy MS, Ganong CA. Cerebral salt wasting in children: the role of atrial natriuretic hormone. Adv Pediatr. 1996;43:271-308.

15. Taylor P, Dehbozorgi S, Tabasum A, Scholz A, Bhatt H, Stewart P, et al. Cerebral salt wasting following traumatic brain injury. Endocrinology, Diabetes \& Metabolism Case Reports [Internet]. 2017 Apr 4 
16. Misra UK, Kalita J, Kumar M. Safety and Efficacy of Fludrocortisone in the Treatment of Cerebral Salt Wasting in Patients With Tuberculous Meningitis: A Randomized Clinical Trial. JAMA Neurology. 2018 Nov 1;75(11):1383.

\begin{tabular}{|c|c|c|c|c|c|}
\hline $\begin{array}{l}\text { Author } \\
\text { (Years) }\end{array}$ & Case & $\begin{array}{l}\text { Head CT - } \\
\text { MRI }\end{array}$ & $\begin{array}{l}\text { Timing to } \\
\text { development } \\
\text { of CSW }\end{array}$ & Treatment & Outcomes \\
\hline $\begin{array}{l}\text { 1- Chaudhary } \\
\text { (11) (2016) }\end{array}$ & $\begin{array}{l}\text { 17-month-old } \\
\text { female: Closed } \\
\text { head trauma, } \\
\text { GCS } 10 / 15\end{array}$ & $\begin{array}{l}\text { Subdural } \\
\text { hematoma, } \\
\text { subarachnoid } \\
\text { hemorrhage, } \\
\text { extradural } \\
\text { hematoma and } \\
\text { contusion }\end{array}$ & 10 days & $\begin{array}{l}\text { Saline hydration } \\
\text { and } \\
\text { Fludrocortisone } \\
200 \mu \mathrm{g} / \text { day }\end{array}$ & Improved \\
\hline $\begin{array}{l}\text { 2- Simsek (12) } \\
(2008)\end{array}$ & $\begin{array}{l}\text { 6-month-old } \\
\text { female: Closed } \\
\text { head \& } \\
\text { cervicothoracic } \\
\text { trauma }\end{array}$ & $\begin{array}{l}8 \mathrm{~mm} \text { benign } \\
\text { congenital } \\
\text { subdural } \\
\text { collection over } \\
\text { frontotemporal } \\
\text { lobes }\end{array}$ & 1 month & Saline hydration & Improved \\
\hline $\begin{array}{l}\text { 3-Askar (13) } \\
(2007)\end{array}$ & $\begin{array}{l}\text { 17-year-old } \\
\text { male: Closed } \\
\text { head trauma \& } \\
\text { multiple injuries } \\
\text { to face, chest, } \\
\text { and pelvis due to } \\
\text { MVA }\end{array}$ & - & 15 days & $\begin{array}{l}\text { Saline Hydration } \\
\text { and } \\
\text { Fludrocortisone } \\
300 \mu \mathrm{g} / \text { day }\end{array}$ & Improved \\
\hline $\begin{array}{l}\text { 4- Steelman (7) } \\
(2008)\end{array}$ & $\begin{array}{l}\text { 9-year-old } \\
\text { male: } \\
\text { Laceration to } \\
\text { chin \& closed } \\
\text { head trauma }\end{array}$ & - & 2 days & Saline hydration & Improved \\
\hline $\begin{array}{l}\text { 5- Berkenbosch } \\
\text { (8) }(2002)\end{array}$ & $\begin{array}{l}\text { 15-year-old } \\
\text { male: Severe } \\
\text { closed head } \\
\text { injury from } \\
\text { cycling accident }\end{array}$ & $\begin{array}{l}\text { right-sided } \\
\text { frontal contusion }\end{array}$ & 2 days & Saline hydration & Improved \\
\hline $\begin{array}{l}\text { 6- Berkenbosch } \\
\text { (8) (2002) }\end{array}$ & $\begin{array}{l}\text { 6-year-old } \\
\text { male: Severe } \\
\text { closed head } \\
\text { injury }\end{array}$ & $\begin{array}{l}1.5 \mathrm{~cm} \text { left } \\
\text { frontoparietal } \\
\text { contusion, } \\
\text { marked diffuse } \\
\text { cerebral edema }\end{array}$ & 6 days & Saline hydration & Improved \\
\hline $\begin{array}{l}\text { 7- Donati-Genet } \\
\text { (10) (2001) }\end{array}$ & $\begin{array}{l}\text { 4-year-old } \\
\text { male: Closed } \\
\text { head injury, } \\
\text { multiple bone } \\
\text { fractures, chest } \\
\text { trauma }\end{array}$ & $\begin{array}{l}\text { Day } 5 \text { CT after } \\
\text { seizure: diffuse } \\
\text { cerebral edema } \\
\& \text { small } \\
\text { cerebellar } \\
\text { hemorrhage }\end{array}$ & 5 days & Saline hydration & Improved \\
\hline
\end{tabular}




\begin{tabular}{|c|c|c|c|c|c|}
\hline $\begin{array}{l}\text { Author } \\
\text { (Years) }\end{array}$ & Case & $\begin{array}{l}\text { Head CT - } \\
\text { MRI }\end{array}$ & $\begin{array}{l}\text { Timing to } \\
\text { development } \\
\text { of CSW }\end{array}$ & Treatment & Outcomes \\
\hline $\begin{array}{l}\text { 8- Kappy (14) } \\
\text { (1996) }\end{array}$ & $\begin{array}{l}\text { 6-month-old } \\
\text { male: MVA } \\
\text { with normal } \\
\text { initial } \\
\text { evaluation. Over } \\
\text { next } 2 \text { months, } \\
\text { vomiting \& } \\
\text { increasing head } \\
\text { circumference }\end{array}$ & $\begin{array}{l}2 \text { months } \\
\text { post-accident } \\
\text { bilateral } \\
\text { subdural fluid } \\
\text { accumulation }\end{array}$ & 2 months & Saline hydration & Improved \\
\hline $\begin{array}{l}\text { 9- Ganong (9) } \\
\text { (1993) }\end{array}$ & $\begin{array}{l}\text { 5-year-old } \\
\text { male: Closed } \\
\text { head injury due } \\
\text { to MVA }\end{array}$ & - & 2 days & Saline hydration & Improved \\
\hline
\end{tabular}

Table 1: Summary of pediatric case reports examining cerebral salt wasting after traumatic brain injury

CSW: cerebral salt wasting; CT: computer tomography; MRI: magnetic resonance imaging; GCS: Glasgow coma scale; MVA: motor vehicle accident 